\title{
A Structural Model Proposal for Turkish Faculties of Education Regarding ICT Integration Indicators*
}

\author{
Yavuz Akbulut \\ Anadolu University, Turkey
}

\begin{abstract}
A recent survey study with 2515 pre-service teachers suggested an underlying structure to shelter ICT integration indicators. Eleven indicators were extracted, which were TeachingLearning Methods, E-learning, E-interaction, Learning Communities, Infrastructure, Access, Ease of Use, Technical Assistance, Policy, Special Education and Health. In addition, the study provided interrelationships among variables which could lead to an ICT integration model for teacher training institutions. The current study administered the survey to 255 pre-service teachers to confirm the suggested factor structure. Based on the relationships among constructs that were provided in the previous study, second-order analyses were conducted revealing a potential pathway to an ICT integration model. The model indicated that the Policy of the institutions was at the center predicting Infrastructure, Special Education, Health and Teaching-Learning Methods. Infrastructure predicted Access, Ease of Use and Technical Assistance; whereas Teaching-Learning Methods predicted Einteraction, E-learning and Learning Communities. Implications and recommendations for further research are provided.
\end{abstract}

Keywords: Country-specific developments; Post-secondary education; Teacher training; ICT integration; Structural equation modeling

\section{Introduction}

Current practices in the workplace evolving with emerging information and communication technologies (ICT) urge individuals to have the ability to use ICTs with confidence and efficiency. ICTs were reported as a predictor of economic growth and job creation (Campbell, 2001). There are even instances indicating that the more ICTs are used, the more productivity gains are reported (Bresnahan, Brynjolfsson, \& Hitt, 1999). Regarding that ICTs are crucial in terms of lifelong learning, an enormous challenge for educators awaits since they are supposed to equip students with relevant and high quality ICT experience before students emerge into the workplace (Gibson, O'Reilly, \& Hughes, 2002).

In general, Faculties of education carry considerable importance to shape the technology use competencies of the future workforce. Positive experiences with ICTs help students to transfer these experiences to their own lives (Mueller, Wood, Willoughby, Ross \& Specht, 2008). In addition, it is not reasonable to expect learners to use ICTs responsibly and effectively if they are not exposed to relevant experiences (Barton \& Haydn, 2006). In this regard, besides

\footnotetext{
* The first draft of the current study was presented in the $10^{\text {th }}$ International Educational Technology Conference, and published in the conference proceedings.
} 
research endeavors on teacher competency, strengths and weaknesses of teacher training institutions should be investigated.

Several studies addressed ICT integration in the compulsory education level (Eteokleous, 2004; Pompeo, 2004). Faculty's adoption of emerging technologies for instructional purposes (Shafiei, 2005) and the integration of ICTs into teacher training curriculum have been reported as well (Toledo, 2005). In addition, proposals to prepare future teachers to use ICTs (Smith \& Robinson, 2003), teachers' integration of ICTs into mainstream classroom practice (Hennessy, Ruthven, \& Brindley, 2005), approaches to ICT use in teacher training (Jung, 2005), and measurement tools to investigate teacher attitudes towards ICTs (Lin, 2005; Liu \& Huang, 2005) have been investigated.

When the Turkish context is under scrutiny, it can be observed that comprehensive investigations have been robust and informatory for K-12 settings (Akbaba-Altun, 2006; Goktas, Yildirim \& Yildirim, 2008; Ozdemir \& Kilic, 2007; Yucel, Acun, Tarman \& Mete, 2010), but relatively insufficient in higher education settings. Among limited number of studies, Gulbahar (2008) argued that teacher training programs did not facilitate the effective integration and use of ICTs for instructional purposes. On the other hand, Yucel et al. (2010) found that ICT knowledge of teachers was a crucial variable in ICT integration, which underlined the importance of teacher training institutions to facilitate ICT integration practices in formal instructional settings. In this regard, institutional evaluations are necessary. That is, investigations reflecting the ICT integration levels of teacher training institutions are needed, and conducting these investigations through the perspectives of primary participants (i.e. preservice teachers) could lead to fruitful analyses.

In order to diagnose the overall picture of an educational institution with regard to ICT indicators, Akbulut, Kesim and Odabasi (2007) developed a measure. While doing so, successful ICT integration indicators were determined according to those stated by UNESCO (2002). More specifically, (a) content and pedagogy issues, (b) collaboration and networking issues, (c) social issues, and (d) technical issues were considered as main headings each sheltering further subtitles. While determining subtitles of these four competencies, Akbulut et al. (2007) resorted to the Odabasi et al. (2006) report and maintained subcomponents of each competency as shown in Table 1.

Table 1. ICT integration competencies

\begin{tabular}{ll}
\hline Competency & Subcomponents \\
\hline Content and Pedagogy & (1) Teaching-Learning methods, (2) ICT in the Curriculum \\
Collaboration and Networking & (3) Professional Development, (4) Learning Communities \\
Social Issues & (5) Health, (6) Special Needs, (7) Ethics, (8) Policy, \\
Technical Issues & (9) Infrastructure, (10) Ease of Use, (11) Access, (12) Technical Assistance \\
\hline
\end{tabular}

Based on the framework given in Table 1, Akbulut et al. (2007) piloted a 54-item survey with 359 college of education students at a Turkish state university, eliminated 13 of those items through exploratory and confirmatory factor analyses and retained ten of 12 components except for Learning Communities and Technical Assistance, as items addressing those components were either shadowed by or merged with others. However, the number and coverage of items in each title were considered insufficient for a reliable administration. Thus, Akbulut (2008) developed new items for each competency and administered the revised 75- 
item form to 2515 pre-service teachers (i.e. fourth year students) in six education faculties in Turkey, which were randomly selected from hierarchically ordered clusters. Even though each competency had acceptable internal consistency coefficients, factor analyses did not lead to a factor structure consistent with the framework at the inception. Thus, the long-followed framework was not retained anymore and a new structure was proposed by Akbulut (2009). The new factor structure included E-learning, Infrastructure, Teaching-Learning Methods, Policy, Special Education, Health, Learning Communities, Ease of Use, E-interaction, Technical Assistance and Access. In the new structure, some constructs were suppressed (i.e. ICT in the Curriculum, Professional Development, Ethics); whereas new communication and learning constructs addressing emerging technologies were included (i.e. E-learning and E-interaction). In addition, suggestive stepwise regression analyses revealing interesting relationships among variables were provided as shown in Table 2.

Table 2. Best predictors of each indicator

\begin{tabular}{ll}
\hline Indicator & Best predictors \\
\hline E-learning & Teaching-Learning Methods, E-interaction, Ease of Use \\
\hline Infrastructure & Access, Health, Ease of Use, Teaching-Learning Methods, Policy, Technical Assistance \\
\hline Teaching-Learning Methods & Learning Communities, E-Learning, Infrastructure \\
\hline Policy & $\begin{array}{l}\text { Special Education, Ease of Use, Teaching-Learning Methods, Health, E-Interaction, } \\
\text { Technical Assistance }\end{array}$ \\
\hline Special Education & Policy, Ease of Use \\
\hline Health & Infrastructure, Learning Communities, Technical Assistance, Access, Policy \\
\hline Learning Communities & Teaching-Learning Methods, E-Interaction, Health \\
\hline Ease of Use & Policy, Access, Technical Assistance, E-Interaction, Infrastructure \\
\hline E-interaction & Learning Communities, E-Learning, Policy, Ease of Use \\
\hline Technical Assistance & Ease of Use, Access, Health, Policy, Infrastructure \\
\hline Access & Infrastructure, Ease of Use, Technical Assistance, Health \\
\hline
\end{tabular}

Considering the reliable and consistent factor structure proposed in the study and examining the interrelationships provided, a covert ICT integration model underlying the study can be proposed. Through the help of the current literature and a new dataset for confirmation, the model was examined in the current study (Figure 1). The dynamics of learning organizations (Senge, 1990), the importance of contributive instructional technology management (Gay, Mahon, Devonish, Alleyne, \& Alleyne, 2006), the significance of planning and management through resorting to all organization members (Lauerma, 2000), and effective management and collaboration (Mehra \& Mital, 2007; Sife, Lwoga, \& Sanga, 2007) were considered, which urged the researcher to center Policy as a predictor of other main constructs in the model: Infrastructure, Special Education, Health and Teaching-Learning Methods.

Infrastructure should predict Access, Ease of Use, and Technical Assistance since one cannot think of these three without Infrastructure. The lack of sufficient infrastructure is reported a primary barrier to successful technology integration in several resources (e.g. Akbaba-Altun, 2006; Clarke, 2007; Goktas et al., 2008; Odabasi, 2000; Ololube, 2006; Pelgrum, 2001; Rajesh, 2003; Reddy \& Srivastava, 2003; Williams, Coles, Wilson, Richardson, \& Tuson, 2000). Infrastructure is the first step in terms of hardware; however, rich infrastructure should be accompanied with opportunities to access those facilities so that the integration becomes more effective (Kling, 2000; Rajesh, 2003; Warschauer, 2003a\&b). Students may have 7/24 accessible hardware, but constant assistance is needed to use them effectively and responsibly. In this regard, Ease of Use (Chang \& Tung, 2008; Chin \& Todd, 1995; Doll, Xia \& Torkzadeh, 1994; Mehra \& Mital, 2007; Odabasi, 2000) and Technical Assistance (Alexander, 
McKenzie \& Geissinger, 1998; Cornelius \& Glasgow, 2007; Hutinger \& Johanson, 2000; Lauerma, 2000; Tallent-Runnels et al., 2006) are further indicators which are supposed to follow infrastructure.

Teaching-Learning Methods predicted E-interaction, E-learning and Learning Communities. Teaching-Learning Methods was centered among these interrelated variables. Students tend to live as they are preached in terms of their ICT use experiences (Barton \& Haydn, 2006; Mueller et al., 2008; Steketee, 2006), and the model person for these experiences is observed through the help of the indicator named Teaching-Learning Methods. Moreover, emerging technologies in educational settings required new teaching methods (Hayes, 2007). If students do not observe the reflections of emerging technologies in their own classrooms, this means that current collaborative practices facilitated through emerging technologies could be insufficient. In brief, the present paper aimed to confirm the factor structure of the scale developed by Akbulut (2009) first. Then, it tested the covert ICT integration model through administering the Akbulut (2009) scale to pre-service teachers enrolled at an education faculty in Turkey.

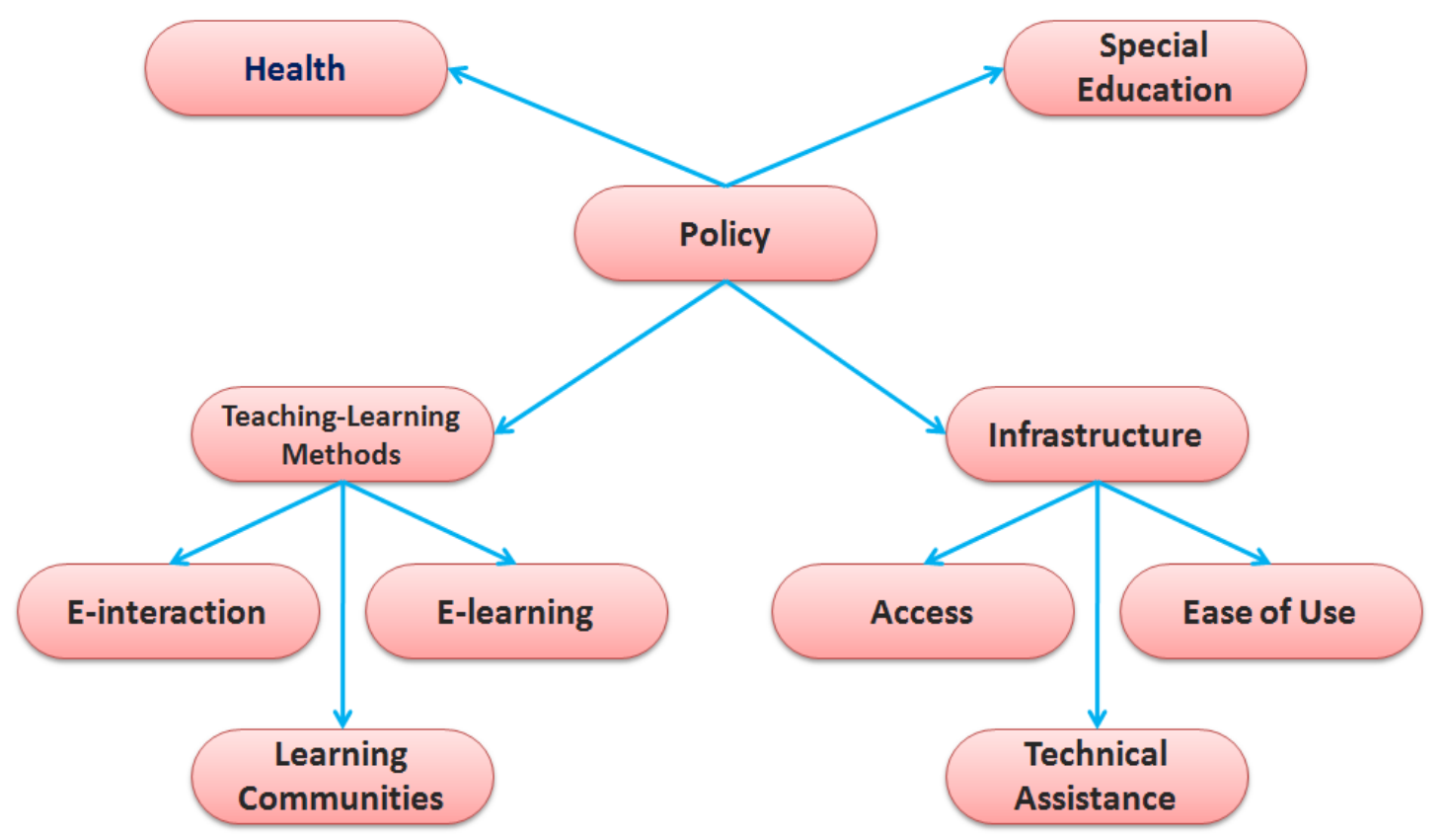

Figure 1. The conceptual diagram of the model

\section{Methods and Procedures}

\section{Participants}

To confirm the factor structure proposed by Akbulut (2009) through a new dataset, the questionnaire was administered to 255 education faculty students at a Turkish state university. The sample produced the Kaiser-Meyer-Olkin Measure of Sampling Adequacy (KMO) as .82, 
which is considered good for factor analysis in several resources (Field, 2000; Hutcheson \& Sofroniou, 1999; Pallant, 2001). Of 255 participants, 165 (65\%) were females and 83 (33\%) were males, whereas six participants $(2 \%)$ did not indicate their genders. Respondents from different departments were available as English Language Teaching $(f=69 ; 27.1 \%)$, Pre-school Education $(f=45 ; 17.6 \%)$, Mathematics Education $(f=31 ; 12.2 \%)$, Computer Education $(f=29$, $11.4 \%)$, German Language Teaching $(f=26,10.2 \%)$, Social Studies Education $(f=23 ; 9 \%)$, French Language Teaching $(f=19 ; 7.5 \%)$ and Fine Arts Education $(f=13 ; 5.1 \%)$.

\section{Data Collection}

The 61-item data collection tool reported by Akbulut (2009) was used to collect data (see Appendix for sample items). Akbulut (2009) administered a personal information form followed by 75 scaled items to address aforementioned ICT integration indicators (Table 1). The degree of agreement with a statement was evaluated on 5-item scales ranging from strongly disagree (1) to strongly agree (5). A large scale administration of the data collection tool with 2515 Turkish pre-service teachers was followed by exploratory and confirmatory factor analyses, which led the researcher delete 14 items, propose an 11-factor structure explaining $64 \%$ of the total variance with a high internal consistency coefficient $(\alpha=.956)$. Remaining 61 items in the data collection tool constituted the scale of the current study.

The internal consistency of the whole scale was 0.96 for the current administration. Corrected item total correlations were above 0.30 suggesting an ideal consistency (Pallant, 2001), and the average of item total correlations was 0.51 . Internal consistency coefficients of individual factors for the current implementation along with the number of items in each factor were given in Table 3. In brief, internal consistency coefficients for the whole scale and for individual factors were all satisfactory.

Table 3. Factors of the scale

\begin{tabular}{lcc}
\hline Factor & Item N & Alpha \\
\hline E-learning & 6 & 0.94 \\
Infrastructure & 7 & 0.89 \\
Teaching-Learning Methods & 8 & 0.84 \\
Policy & 7 & 0.87 \\
Special Education & 6 & 0.82 \\
Health & 6 & 0.89 \\
Learning Communities & 6 & 0.86 \\
Ease of Use & 4 & 0.89 \\
E-interaction & 4 & 0.80 \\
Technical Assistance & 3 & 0.87 \\
Access & 4 & 0.80 \\
Total & 4 & 0.96 \\
\hline
\end{tabular}

An official permission letter was received from the institution to implement the tool, which was administered to senior grade education faculty students at the end of the 2008 Fall semester. Responding took 11 to 15 minutes. After the dataset was checked for bad or missing values, the factor structure of the scale was processed through LISREL 8.51 (Joreskog \& Sorbom, 2001). 


\section{Results}

When the means of each indicator were examined, it was observed that participants harshly criticized the current situation of ICT indicators in their institution. None of the factor means was even close to the medium value (i.e.3), and one-sample t-tests revealed that all factor means were significantly lower than the medium value of 3 (out of 5) at a probability value below 0.001 . The scope of the study was to delve into interrelationships among constructs rather than describing the current situations, strengths or weaknesses of the teacher training institutions in Turkey. Thus, further analyses on descriptives were not included here.

The confirmatory factor analysis (CFA) was conducted to examine the adequacy of how well the current data fit the factor structure suggested in Akbulut (2009). An ideal Chi-square / df ratio (3082/1714=1.8) (Sumer, 2000) along with an acceptable Root Mean Square Error of Approximation (RMSEA=0.057) (Browne \& Cudeck, 1993) was observed. None of the t-values was below significance and the fit indices were marginally below the acceptable fit values (Comparative Fit Index [CFI]:0.87; Incremental Fit Index [IFI]: 0.87; Goodness of Fit Index [GFI: 0.80]; Adjusted Goodness of Fit Index [AGFI] $=0.77$ ). GFI and AGFI are given here on purpose, as there is a tendency to report these values. However, an expert in the field, David A. Kenny suggests in his personal website (http://davidakenny.net) that the current consensus is not to use these measures as they are generally affected by the sample size. In addition to above indices, the standardized root mean square residual (SRMR) was 0.066, which is below the threshold of 0.10 to consider the value favorable (Kline, 2005).

As summarized, the first trial to confirm the model was mostly successful. Taking the abundance of observed variables, above values can be considered satisfactory. However, to make the model better than 'acceptable', some modifications might be suggested. Rather than adding every single path or error covariance among variables, some slightly problematic items could be deleted so that the fit values became more favorable. When item 29 from Learning Communities, item 35 and 36 from Infrastructure, item 13 and 14 from Teaching-Learning Methods were deleted, most fit indices happened to be higher than 0.90, Chi-square / df ratio became better $(1964 / 1429=1.37)$, the RMSEA became 0.043, and the SRMR became 0.057. All these values indicated a good fit. In this regard, while administering the scale developed by Akbulut (2009), researchers may prefer to eliminate those items for practicality, and use the 56-item version revealed here.

The most robust choice is to re-confirm the factor structure whenever any modifications on the scale are conducted. In this regard, as the original 61-item form revealed acceptable or marginally acceptable fit values according to liberal views on fit index thresholds, that version might be implemented as well. Actually, choosing between the original 61-item form with marginally acceptable values and the aforementioned modified-but-unconfirmed form with more acceptable values is up to scholars' preferences regarding their unique research context and purposes.

For the second order analysis, the structure implied by Akbulut (2009) was taken into account. The model whose conceptual diagram is provided in Figure 1 was tested. An ideal Chi square / df ratio (2269/1474=1.54), acceptable RMSEA (0.052) and SRMR (0.09) values were observed accompanied by marginally high fit indices (IFI: 0.87; CFI: 0.87; GFI: 0.81; AGFI: 0.78). Through adding error covariances between E-interaction and E-learning, E-interaction and Teaching- 
Learning Methods, Technical Assistance and Ease of Use, Access and Ease of Use, Health and Infrastructure, it was possible to increase the fit indices to 0.90 , reduce the RMSEA to .05 , and improve the Chi square / df ratio to 1.52 .

Creating two different variables as E-interaction and E-learning raised the question whether it was necessary to separate them. Combining the two in an alternative model was problematic as this application increased the Chi square / df ratio about ten percent (1.70), worsen the RMSEA (0.06), the SRMR (0.10) and the fit indices (IFI: 0.84; CFI: 0.84; GFI: 0.78; AGFI: 0.75).

Rather than adding error covariances between the aforementioned variables, an alternative model can also be created by combining latent variables predicted by Infrastructure under a single title, and variables predicted by Teaching-Learning Methods under a single title. Such a model put the Policy into the center of the model again, but the other four variables were only Infrastructure, Teaching-Learning Methods, Special Education and Health. Such a model had a weaker chi square / df ratio $(3983 / 1480=2.69)$, an unacceptable RMSEA value $(0.092)$, a weaker SRMR (0.089), and lower fit indices (IFI: 0.73; CFI: 0.73; GFI: 0.65). This trial revealed the importance and unique contributions of individual variables for the first model.

The best model confirmed in the current study along with the items and standardized solutions is provided in Figure 2.

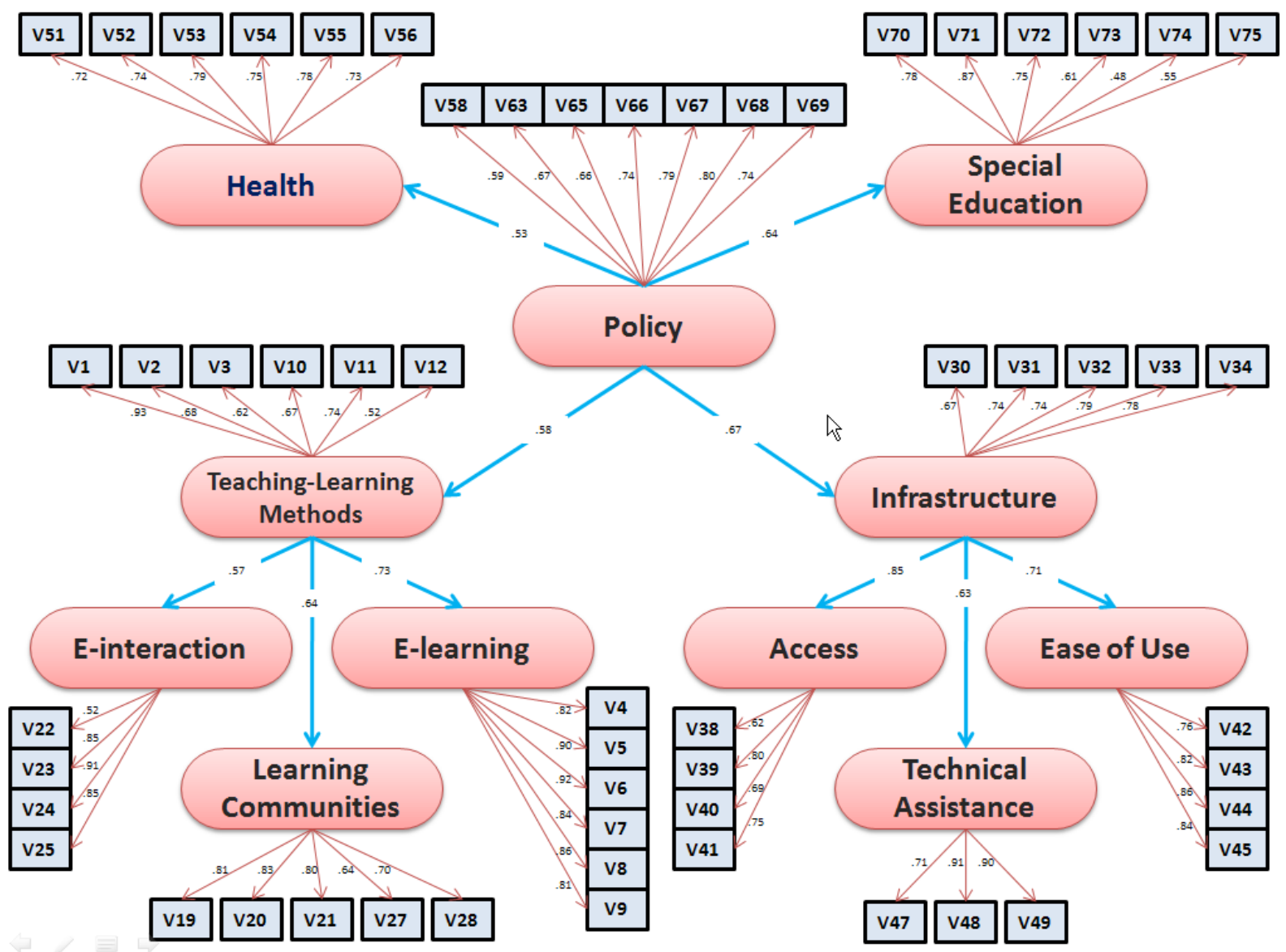

Figure 2. The model with items and standardized solutions 


\section{Discussion and Conclusion}

Confirmation of the factor structure and the model centering on Policy as the predictor of Infrastructure, Special Education, Health and Teaching-learning Methods were successful to a great extent for the current administration. This suggests that successful ICT integration could primarily be an administrative issue. More specifically, improvements in terms of Policy indicators can reflect themselves in other variables. Recent international studies reporting cases from Turkey partially support this assumption and maintain that the integration of ICTs into teaching needs to overcome organizational as well as political obstacles (Gulbahar \& Guven, 2008); clearly, administration is among important ICT implementation issues (AkbabaAltun, 2006). These two studies and another recent study by Goktas, Yildirim and Yildirim (2009) underline the importance of infrastructure, which is highly interrelated with other ICT integration constructs, but primarily predicted by policy in the current study. A limitation of the current indicators with regard to policy was that items mostly focused on the disclosure policy of administrators. In this regard, further items are needed to address different aspects of the policy indicators. Furthermore, the setting of the current study reflected characteristics of a strict hierarchy along with a large power distance index. Thus, the findings might be refuted in a setting where the ways people perceive power differences are different.

Observed variables covered by the latent constructs of Access, Ease of Use and Technical Assistance were primarily predicted by Infrastructure. Without infrastructure, it is impossible to think about indicators like accessibility, ease of use and technical assistance. In this regard, these interrelationships were expected. Finally, the ICT integration quality of TeachingLearning Methods predicted the quality of E-interaction, E-learning and Learning Communities simultaneously. Stated differently, the quality of distributed learning and educational communication endeavors in education faculties is reflected best through the construct of Teaching-Learning Methods. This construct included items addressing effective, creative, motivating and relevant uses of emerging technologies by instructors during their instructional activities. These interrelationships suggested that if instructors could not use emerging technologies for instruction in a relevant and effective way, other practices reflecting elearning, e-interaction and learning communities may also fail.

The notions of information transparency and accessibility vary among educational institutions. One cannot access all details regarding the ICT infrastructure of different institutions in a standardized way since some constructs are either naturally latent or ambiguous depending on the context. Moreover, constructs examined in the current study are inherently related in terms of ICT integration into formal educational settings. Thus, proposing structural equation models through measurable constructs, and investigating interrelationships among these constructs can help scholars to diagnose the current ICT integration situations of their institutions.

The current study poses several limitations urging us to reconsider the items and the structural model constantly. As indicated, five items were somewhat problematic and should be reworded or replaced with new items addressing current practices, and piloted with a large enough sample to improve the scale. Even if the structural model is useful for the time being, items and sub-constructs should be modified in accordance with the developments in the field. In addition, the confirmation of the current structural model which is 'currently plausible for a Turkish education faculty' should be extended to alternative educational settings. Another important limitation is that observed variables defining each latent construct in the current study should be organized as a combination of different objective and reliable measures. Each 
latent construct addressed here can be a theme for a $\mathrm{PhD}$ dissertation or a large-scale research endeavor to be examined through comprehensive scales. However, limited number of items was used to define a latent construct all of which were subcomponents of a single scale in the current study. In this regard, further measures for each latent construct should be implemented so that the current model can be developed further or refuted completely.

Higher education dynamics in Turkey change in such a rapid way that the nature of the target population changes before the findings illustrating the current situation is published. For instance, before Akbulut (2008) completed his study with a considerably large sample from Turkish teacher training institutions, new universities and education faculties were founded, quotas of existing departments were increased, expelled students were given a chance to pursue their education, high schools were prolonged giving a higher chance to those who could not pass the university entrance exam the previous year since many high school seniors could not graduate that year. That is, even if researchers collect data from large enough samples that are representative of the target population, the population they represent expires before the implications and suggestions are provided, somewhat urging scholars to generalize beyond justified limits. Such a constant and rapid change in the higher education system in a mysterious direction also prevents researchers to confirm their scale modifications on time. Thus, ICT integration and scholarly work on the issue is an ongoing and tiresome process as the characteristics of the population change before the large scale needs assessments are complete in addition to usual developments in the field of instructional technology.

\section{References}

Akbaba-Altun, S. (2006). Complexity of integrating computer technologies into education in Turkey. Educational Technology \& Society, 9(1), 176-187.

Akbulut, Y. (2008). Ogretmen adaylarinin bakis acisiyla egitim fakultelerinde bilgi ve iletisim teknolojileri gostergelerinin belirlenmesi (Exploration of the indicators of information and communication technologies at education faculties through pre-service teachers' viewpoints). Unpublished PhD Dissertation. Anadolu University, Eskisehir, Turkey.

Akbulut, Y. (2009). Investigating underlying components of the ICT indicators measurement scale: the extended version. Journal of Educational Computing Research, 40(4), 405-427.

Akbulut, Y., Kesim, M., \& Odabasi, H. F. (2007). Construct validation of ICT indicators measurement scale (ICTIMS). The International Journal of Education and Development Using Information and Communication Technology (IJEDICT), 3(3), 60-77.

Alexander, S., McKenzie, J., \& Geissinger, H. (1998). An evaluation of information technology projects for university learning: Executive summary. Retrieved October 19, 2010 from http://www.dest.gov.au/archive/cutsd/publications/exsummary.html

Barton, R. \& Haydn, T. (2006). Trainee teachers' views on what helps them to use information and communication technology effectively in their subject teaching. Journal of Computer Assisted Learning, 22, 257-272.

Bresnahan, T., Brynjolfsson, E., \& Hitt, L. M. (1999). Information technology, workplace organization, and the demand for skilled labor: Firm-level evidence. Working Paper No. 7136. Cambridge, MA: National Bureau of Economic Research. 
Browne, M. W. \& Cudeck, R. (1993). Alternative ways of assessing model fit. In K. A. Bollen \& J. S. Long (Eds.), Testing structural equation models (pp.136-162). Newbury Park, CA: Sage Publications.

Campbell, D. (2001). Can the digital divide be contained? The digital divide: employment and development implications. International Labour Review, 140(2), 119-141.

Chang, S. C. \& Tung, F. C. (2008). An empirical investigation of students' behavioral intentions to use the online learning course websites. British Journal of Educational Technology, 39(1), 71-83.

Chin, W. C. \& Todd, P. A. (1995). On the use, usefulness and ease of use of structural equation modeling in MIS research: a note of caution. MIS Quarterly, 19(2), 237-246.

Clarke, P. J. (2007). Exploring the use of computer technology in a Caribbean context: Views of pre-service teachers. International Journal of Education and Development using Information and Communication Technology (IJEDICT), 3(1), 23-38.

Cornelius, F. \& Glasgow, M. E. S. (2007). The development and infrastructure needs required for success - one college's model: Online nursing education at Drexel University. TechTrends, 51(6), 32-35.

Doll, W. J., Xia, W. \& Torkzadeh, G. A. (1994, December). A confirmatory factor analysis of the End-User Computing Satisfaction Instrument. MIS Quarterly, 18, 453-461.

Eteokleous, N. P. (2004). Computer technology integration in Cyprus elementary schools. Unpublished Ph.D. Thesis. The Pennsylvania State University, PA, USA.

Field, A. (2000). Discovering statistics using SPSS for windows. London: Sage Publications.

Gay, G., Mahon, S., Devonish, D., Alleyne, P. \& Alleyne, P. G. (2006). Perceptions of information and communication technology among undergraduate management students in Barbados. International Journal of Education and Development using Information and Communication Technology (IJEDICT), 2 (4), 6-17.

Gibson, I. S., O'Reilly, C., \& Hughes, M. (2002). Integration of ICT within a project-based learning environment. European Journal of Engineering Education, 27(1), 21-30.

Goktas, Y., Yildirim, Z., \& Yildirim, S. (2008). The keys for ICT integration in K-12 education: Teachers' perceptions and usage. Hacettepe University Journal of Education, 34, 127139.

Goktas, Y., Yildirim, S., \& Yildirim, Z. (2009). Main barriers and possible enablers of ICTs integration into pre-service teacher education programs. Educational Technology \& Society, 12(1), 193-204.

Gulbahar, Y. (2008). ICT usage in higher education: A case study on preservice teachers and instructors. The Turkish Online Journal of Educational Technology, 7(1), 32-37.

Gulbahar, Y. \& Guven, I. (2008). A survey on ICT usage and the perceptions of social studies teachers in Turkey. Educational Technology \& Society, 11(3), 37-51.

Hayes, D. N. A. (2007). ICT and learning: Lessons from Australian classrooms. Computers \& Education, 49(2), 385-395.

Hennessy, S., Ruthven, K., \& Brindley, S. (2005). Teacher perspectives on integrating ICT into subject teaching: commitment, constraints, caution and change. Journal of Curriculum Studies, 37(2), 155-192. 
Hutcheson, G. \& Sofroniou, N. (1999). The multivariate social scientist. London: Sage.

Hutinger, P. L. \& Johanson, J. (2000). Implementing and maintaining an effective early childhood comprehensive technology system. Topics in Early Childhood Special Education, 20(3), 159-173.

Joreskog, K. G. \& Sorbom, D. (2001). LISREL 8.51. Chicago, IL: Scientific Software, Inc.

Jung, I. (2005). ICT-pedagogy integration in teacher training: application cases worldwide. Educational Technology \& Society, 8(2), 94-101.

Kline, R. B. (2005). Principles and practice of structural equation modeling (Second edition). New York: The Guilford Press.

Kling, R. (2000). Learning about information technologies and social change: The contribution of social informatics. The Information Society, 16, 217-232.

Lauerma, A. (2000). Utsjoki: An example of implementing ICT in school environment in Lapland. Turkish Online Journal of Distance Education, 1(1), 37-42. Retrieved October 19, 2010 from http://tojde.anadolu.edu.tr/tojde1/index.html

Lin, L. J. C. (2005). Development of a questionnaire for determining the factors in technology integration among teachers. Journal of Instructional Psychology, 32(4), 287-292.

Liu, Y. \& Huang, C. (2005). Concerns of teachers about technology integration in the USA. European Journal of Teacher Education, 28(1), 35-47.

Mehra, P., \& Mital, M. (2007). Integrating technology into the teaching-learning transaction: Pedagogical and technological perceptions of management faculty. International Journal of Education and Development using Information and Communication Technology (IJEDICT), 3 (1), 105-115.

Mueller, J., Wood, E., Willoughby, T., Ross, C., \& Specht, J. (2008). Identifying discriminating variables between teachers who fully integrate computers and teachers with limited integration. Computers \& Education, 51(4), 1523-1537.

Odabasi, F. (2000). Faculty use of technological resources in Turkey. Innovations in Education and Training International, 37(2), 103-107.

Odabasi, F., Akbulut, Y., Cuhadar, C., Dursun, O. O., Kabakci, I., Kilicer, K., Kurt, A. A., Sendag, S., \& Tanyeri, T. (2006). A proposal for baseline study on ICT integration. Ankara: Ministry of National Education Projects Coordination Center. Retrieved October 19, 2010 from http://home.anadolu.edu.tr/ fodabasi/doc/ey6.swf

Ololube, N. P. (2006). Appraising the relationship between ICT usage and integration and the standard of teacher education programs in a developing economy. International Journal of Education and Development using Information and Communication Technology (IJEDICT), 2(3), 70-85.

Ozdemir, S. \& Kilic, E. (2007). Integrating information and communication technologies in the Turkish primary school system. British Journal of Educational Technology, 38, 907-916.

Pallant, J. (2001). SPSS survival manual. Maidenhead, PA: Open University Press.

Pelgrum, W. J. (2001). Obstacles to the integration of ICT in education: Results from a worldwide educational assessment. Computers \& Education, 37(2), 163-178.

Pompeo, J. M. (2004). A study of computer integration on public secondary schools. Unpublished Ph.D. Thesis. The State University of New Jersey, NJ, USA. 
Rajesh, M. (2003). Study of the problems associated with ICT adaptability in developing countries in the context of distance education. Turkish Online Journal of Distance Education, 4(2), Retrieved October 19, 2010 from http://tojde.anadolu.edu.tr/tojde10/ index.htm

Reddy, V. V. \& Srivastava, M. (2003). ICT \& the future of distance education. Turkish Online Journal of Distance Education, 4 (4), Retrieved October 19, 2010 from http://tojde.anadolu.edu.tr/tojde12/index.htm

Senge, P. M. (1990). The fifth discipline: The art and practice of the learning organization. New York, NY: Doubleday.

Shafiei, M. (2005). Factors contributing to participation in faculty development and integration of computer technology in the community college. Unpublished Ph.D. Thesis. University of Houston, TX, USA.

Sife, A. S., Lwoga, E.T., \& Sanga, C. (2007). New technologies for teaching and learning: Challenges for higher learning institutions in developing countries. International Journal of Education and Development using Information and Communication Technology (IJEDICT), 3(2), 57-67.

Smith, S. J., \& Robinson, S. (2003). Technology integration through collaborative cohorts: Preparing future teachers to use technology. Remedial and Special Education, 24 (3), 154-160.

Steketee, C. (2006). Modeling ICT integration in teacher education courses using distributed cognition as a framework. Australasian Journal of Educational Technology, 22(1), 126144.

Sumer, N. (2000). Yapisal esitlik modelleri: Temel kavramlar ve ornek uygulamalar (Structural equation models: Basic principles and sample applications). Turkish Psychological Articles, 3(6), 49-74.

Tallent-Runnels, M. K., Thomas, J. A., Lan, W. Y., Cooper, S., Ahern, T. C., Shaw, S. M., \& Liu, X. (2006). Teaching courses online: A review of the research. Review of Educational Research, 76(1), 93-135.

Toledo, C. (2005). A five-stage model of computer technology integration into teacher education curriculum. Contemporary Issues in Technology and Teacher Education, 5(2), 177-191.

UNESCO (2002). Information and communication technologies in teacher education: A planning guide. Retrieved October 19, 2010 from, http://unesdoc.unesco.org/images/0012/ 001295/129533e.pdf

Warschauer, M. (2003a). Demystifying the digital divide. Scientific American, 289(2), 42-47.

Warschauer, M. (2003b). Dissecting the digital divide: A case study in Egypt. The Information Society, 19(4), 297-304.

Williams, D., Coles, L., Wilson, K., Richardson, A., \& Tuson, J. (2000). Teachers and ICT: Current use and future needs. British Journal of Educational Technology, 31(4), 307-320.

Yucel, C., Acun, I., Tarman, B., \& Mete, T. (2010). A model to explore Turkish teachers' ICT integration stages. The Turkish Online Journal of Educational Technology, 9(4), 1-9. 


\section{Appendix - Sample items within each factor of the scale ${ }^{*}$}

\begin{tabular}{l}
\hline E-learning \\
\hline Instructors offer their courses embedded with e-learning contexts. \\
Instructors encourage us to use online learning environments. \\
Instructors consider the activities in online learning environments during evaluation. \\
\hline Infrastructure \\
\hline Computers are fast enough to be used for instructional activities. \\
There is sufficient number of computers for students in laboratories. \\
\hline Teaching-learning methods \\
\hline Instructors select and implement technologies appropriate for our needs. \\
Instructors try to use instructional technologies sustaining higher level of interest. \\
\hline The administration applies to our opinions about new implementations. \\
The administration guides us in following the technological innovations. \\
We are allowed to participate in decision making processes regarding innovations.
\end{tabular}

\section{Special Education}

There are materials appropriate for students with special needs.

The physical conditions of the classrooms are appropriate for students with special needs.

Health

Tables and chairs are appropriate for comfortable use of computers.

Technology classrooms and laboratories are regularly ventilated.

Physical conditions like class setting, temperature, lighting, and seating arrangement are appropriate for instruction.

\section{Learning communities}

Instructors give importance to regular professional development.

Instructors make use of samples helping us to know different cultures.

Instructors encourage us to conduct multilateral projects with different universities.

\section{Ease of use}

There are warnings and explanations in technology classrooms which help me use the devices easily. I can easily access information regarding how to use technology classrooms and laboratories.

\section{E-interaction}

Instructors generate online discussion groups about our field.

Instructors encourage us to participate in online discussion groups.

Instructors participate in discussions in our forums.

\section{Technical assistance}

There are sufficient numbers of staff to assist us when we have problems in technology classrooms.

Whenever I have a problem in laboratories, fast and effective technical support is provided.

Access

Technology classrooms and laboratories are available whenever I need.

I can find devices like scanner, printer and video camera whenever I want.

* 28 of 61 items are provided to inform the readers about the nature of the scale. The complete version of the original scale was presented in Akbulut (2009).

Correspondence: Yavuz Akbulut, Assistant Professor, Department of Computer Education and Instructional Technologies, Faculty of Education, Anadolu University, Eskisehir, Turkey. 